\title{
Moral Values and Struggle in the Story of Saba Nan Aluih, From the Region of Padang Tarok Baso, Agam
}

\author{
Abdul Aziz \\ Indonesia Literature Department \\ STAI Nurul Ilmi Tanjung Balai \\ Indonesia \\ abdaaziz08@gmail.com
}

Citation: Aziz, A. (2021). Moral values and struggle in the story of Saba Nan Aluih, from the region of Padang Tarok Baso, Agam. Notion: Journal of Linguistics, Literature, and Culture Vol 3(2), p. 99-104. http://doi.org/hotion.v3i2.4832

\section{Article Info}

Article History

- Article Received

September $9^{\text {th }}, 2021$

- Article Accepted

October $27^{\text {th }}, 2021$

\section{Keywords}

Moral Values

Values of Deliberation

Folklore

Documentation study

Saba Nan Aluih

\section{ABSTRACT}

The values of struggle and moral values in literature are dependent on each other. Literature is strongly influenced by the values of struggle and moral values, so that everything contained in morals and struggles is reflected in literature. Thus, literary works can be approached using the values of struggle and moral values. The problem of this research is about the value of struggle and moral values contained in the folklore of Saba Nan Aluih. The purpose of this study is to describe the description of the values of struggle and moral values in the folklore of Saba Nan Aluih. The data of this study is a description of the values of struggle and moral values in the folklore of Saba Nan Aluih. The method used is descriptive method with qualitative analysis by describing the description of the values of struggle and moral values in the folklore of Saba Nan Aluih. This method is based on consideration of the suitability of the research form with the research objectives. The research instrument was carried out by means of a documentation study. Documentation study was conducted on the folklore of Saba Nan Aluib with an analysis approach to the value of struggle and moral values. From the results of this study, it can be found the results of research on the value of struggle in terms of, the value of self-sacrifice, the value of unity, the value of respect, the value of sabra and unyielding spirit, and the value of cooperation. Based on moral values, moral values in human relations with oneself are divided into, responsibility for education. The moral values of human relations with other humans are divided into, parental advice to children, advice between friends, parental love for children, and child affection for parents. 


\section{INTRODUCTION}

Literature is considered increasingly important because literature is created but continues to be appreciated by the community for refining the mind and enriching spirituality and entertainment and has also been included in the school curriculum as knowledge of the value of struggle and moral values. Mastery of theory is one way of understanding literary works, it can be justified scientifically, even though literature itself is interpretive. For this reason, students majoring in Indonesian language and literature who in fact struggle in the world of literature need to understand and master literature, and through other activities related to literature.

Literary work, as a structure consists of elements that are arranged in a systematic way. Talking about imaginative literature, dealing with three types of literary genres, namely prose, poetry and drama. Prose in a literary sense is also called fiction, narrative text, or narrative discourse. The term fiction in this sense is a fictional story or imaginary story. This is because fiction is a narrative work whose contents do not suggest historical truth as an imaginary work, fiction offers various human and human problems, life and life. One type of prose is folklore, which is a story that comes from the community and developed in society in the past which is a characteristic of every nation that has a diverse culture that includes the rich culture and history of each nation. In general, this folklore tells about an incident in a place or the origin of a place. The characters that appear in folklore are generally manifested in the form of animals, humans and gods.

Research that uses an approach to the value of struggle and cultural values to literary works is a form of creativity in relation to people's lives. In literary works, values or messages will be stored that contain messages or advice. Through his work, the creators of literary works try to influence the mindset of readers and participate in studying about good and bad, rightly taking lessons, examples that should be imitated on the contrary, to be reproached for those who are not good.

Identification in this study is a description of the factors that encourage researchers to conduct research on the analysis of cultural values in the folklore of Saba Nan Aluih. Clarity of problem identification is very necessary as a guide for researchers to facilitate the testing process, avoiding the possibility of deviations in the discussion of the problem.

Given the limitations of the abilities that researchers have, to avoid confusion in the discussion and analysis, the research is limited to an analysis of the description of the values of struggle and moral values in the folklore of Saba Nan Aluih. The problem as the basis for writing, then based on the identification and limitation of the problem in this study is how to describe the value of struggle and moral values in the folklore of Saba Nan Aluih.

Each research must have a clear goal because with a clear goal will make it easier for researchers or readers to examine the problem. Based on the formulation of the problem stated above, in general the purpose of this study is to describe the value of struggle and moral values in the folklore of Saba Nan Aluih. This research is useful both theoretically and practically, this research is an input so that in writing folklore it is more directed to the social life of the community that is happening today. Practically, this research is useful which is expected from the researcher. As input and knowledge for teachers in the field of Indonesian Language and Literature studies, especially in literary studies.

Sanusi[6] argues that value is a system based on interacting, interrelated, and interconnected components. Through this understanding, values are things that refer to good and bad which function to control humans to act according to regulations, both in religion, morals, social which reflects a beauty.

The value of being willing to sacrifice is a spark of one's soul or spirit in facing challenges, both from within and from outside. Spirit is one example of the soul and spirit in which it contains the value of sacrifice. In that event, it was the soul and spirit that moved the Balinese warriors to act in war. Their actions are based on the principle that it is better to die under the ground than to live in the mirror of a carcass, or the principle of freedom or death. 
Joyomartono[1] says that being willing to sacrifice is something that is indispensable in carrying out a struggle. Because without sincere sacrifice, we will never achieve a great success in a struggle.

The value of unity as a continuation of the value of being willing to sacrifice is very important in carrying out a struggle in life. The value of unity includes the understanding of the unification of various patterns that vary into one whole. Indonesian society is a pluralistic society. Various ethnic groups with diverse customs, various religions are embraced, the diversity of languages used is also easy to provide opportunities for differences to arise. However, this difference can be eliminated if all parties have a strong sense of unity. Thus, the basis of our country which reads Bhinneka Tunggal Ika can really be used as a guide for all Indonesian people to interact, and be able to protect the nation and the entire territory of Indonesia. Joyomartono (1990:6) says that the value of unity has been forged throughout the history of the struggle of the Indonesian people, which reached its momentum at the beginning of its development, its maturation process in 1928, and reached its peak in the Proclamation of Independence on August 17, 1945.

As with the value of unity, the value of respect is very important for the process of a struggle. As a cultured society, the Indonesian people have long established relationships on the basis of mutual respect in the process of daily life. Friendships with other people are part of the daily life of Indonesian people. Joyomartono[1] says that the development of the value of respect that has been forged throughout the history of our nation, has finally become a guide for all of us in living in society and the state.

In carrying out a struggle, the value of patience and unyielding spirit is very important. Even though many of our struggles have failed in the early stages, we must remain patient and enthusiastic, we even have to instill an unyielding attitude in each of our struggles. Because with an unyielding attitude and keep trying, one day we will succeed in our struggle. An attitude of unyielding spirit is a key to success in a struggle. If in this process of struggle we have failed, it is a normal thing, and it is not the end of everything if we want to try again. But everything will really end, if in this failure we immediately give up, and success will be farther away forever. Therefore, in carrying out the struggle in this life we must have an attitude of patience, keep the spirit and never give up.

The value of this cooperation is the basis of the Indonesian people who in their daily life like to work together on the basis of the spirit of kinship. The radiance of this cooperative spirit is seen if when the community faces a problem, the community together will first discuss the problem and then work on it together. Joyomartono[1] says that the Indonesian proverb that describes this spirit of cooperation is the one that reads "Light weight is the same as carried, heavy is shouldered". As with other values of struggle, the value of cooperation has also been embedded in the culture of the Indonesian people, for example, such as mutual cooperation and when working together in fighting for the independence of our country.

The understanding of morals in literary works itself is no different from the general understanding of morals, which concerns the generally accepted values of good and bad and stems from human values. Morals in literary works are usually intended as practical instructions and suggestions for readers in everyday life. In this case, Kenny via Nurgiyantoro[4] states that the moral of the story is usually intended as a suggestion related to certain moral teachings that are practical, which can be taken or interpreted through stories related to the reader. It is a "guidance" deliberately given by the author on various matters related to social behavior and manners. It is practical because the "guidance" can be shown, or found a model, in real life, as the model is shown in the story through the attitudes and behavior of the characters. According to Sayuti[7], the moral of the story is usually intended as a rather practical piece of moral advice that can be taken from a story.

Human relationship with God, human relationship with himself, and human relationship with the natural environment. It can be said that in essence literature is closely related to religion, social and individual. As stated above, things in literature will always deal with human problems with God, in relationships with oneself, and in relationships with other humans or nature. 


\section{Aziz, Abdul \\ Moral Values and Struggle in the Story of Saba Nan Aluih, From the Region of Padang Tarok Baso, Agam}

The behavior of human relations with themselves is classified in all forms of moral teachings related to individuals as individuals who show the existence of the individual with various attitudes attached to him. Human problems with themselves via Nurgiyantoro[4] can be of various types and levels of intensity.

Problems between humans and humans in everyday life cannot be separated from the Creator. As humans remember God by doing worship according to the teachings of their religion. Rasjidi[5] states that humans are religious creatures in the sense that they worship God, perform rituals or worship as well as ceremonies to ask forgiveness and regret themselves. Human attitudes and actions in relation to God can be in the form of piety, namely carrying out his orders and staying away from his prohibitions.

Human behavior with God is reflected in the individual in carrying out life with all its problems. Any action in human life will not be separated from God as the creator of nature and its contents, including all creatures. Human relations with God are carried out by praying or other forms that show a vertical relationship with the Almighty in order to ask for guidance, help or as a form of gratitude.

Human relations with other humans in social life, often conflicts of interest occur. The problems of human life with its environment can be in the form of positive problems or negative problems. Given that humans are basically social beings who need each other, including the relationship with the natural surroundings as a completeness in their lives, sometimes it causes various kinds of problems. The friction of interests (rights and obligations) that arise between an individual and another individual as well as with the environment, will usually cause moral problems. Moral problems generally lead to disagreements with the moral principles themselves[2].

\section{METHODOLOGY}

This research is a literature study and activities carried out by collecting and analyzing research data in the folklore of Saba Nan Aluih. The source of this research data is the display in the form of oral or written facts that are observed by the researcher and the objects observed in detail in order to capture the meaning implied in the object document. According to Moleong[3]. The data source of the research is the folklore of Saba Nan Aluib.

The research method is a way to reveal or analyze a problem that is the object of research. To achieve the goals that have been set, the authors need a method. The method is a way of working that must be taken in a scientific research. The method used in this research is descriptive method with qualitative data analysis, a textual study model with an approach to struggle values and moral values. Qualitative descriptive research is research aimed at describing and analyzing natural objects, events, social activities[3]. This study seeks to describe an event in detail, systematically, carefully, and factually regarding aspects of the development of cultural values, in the folklore of Saba Nan Aluib. The research instrument was carried out by means of a documentation study. Documentation study was conducted by analyzing the values of struggle and moral values in the folklore of Saba Nan Aluih. This research was reviewed by taking notes, marking the parts in the form of cultural values and researchers' descriptions that could be considered useful and influential for the reader. The instruments in this research are (1) finding and determining the values of struggle and moral values being studied, (2) tracing the development of the values of struggle and moral values being studied, (3) identifying the various values of struggle and moral values in describing, and classify it.

Data analysis is a very important part of the scientific method, because by analyzing the data data is given meaning and meaning that is useful in solving research problems. The technique used in this research is to determine the data. So the steps taken by the author in the study. Read literature carefully the folklore of Saba Nan Aluib. Researchers read the folklore that became the object of research, in this case the folklore of Saba Nan Alwih. The activity of reading folklore is carried out by skimming techniques to understand the storyline, at the stage of reading comprehension which aims to make researchers understand the problems contained in the folklore studied. Understanding the picture of cultural values in the folklore of Saba Nan Aluih. Reading the evaluation aims to conclude the folklore of Saba Nan Aluib. The problems contained in the folklore of Saba Nan Aluib. Collecting data related to research.

\section{RESULT AND DISCUSSION}


In this study, the researcher first reads in detail the folklore of Saba Nan Aluih, this is done so that researchers gain an understanding of the value of struggle and moral values in the folklore of Saba Nan Aluih with an approach to the value of struggle and moral values. Found the results of the study seen from. the value of struggle in terms of, the value of self-sacrifice, the value of unity, the value of respect, the value of sabra and the spirit of unyielding, and the value of cooperation. Moral values are based, moral values in human relations with God are divided based on faith, praying to God, and prayer, moral values in human relations with oneself are divided into, patience, sincerity, and responsibility for education. The moral values of human relations with other humans are divided into, parental advice to children, advice between friends, parental love for children, child affection for parents, and affection between friends, parental responsibility for children. The following are the results of research on the values of struggle and moral values in the folklore of Saba Nan Aluih.

\section{a. The Value of Struggle in the Folklore of Saba Nan Aluih}

1) The value of self-sacrifice

Rajo Babanding was killed fraudulently in a fight with his best friend who refused his proposal to the Sabai. He was shot by Rajo Nan Panjang's bodyguard from behind. Sabai avenged his father's death, because Mangkutak did not want to be invited. The man also died in the hands of the Sabai and his body was brought home by his wife.

2) Unity value

Hearing this threat, Rajo Babanding did not feel the least bit afraid. He again challenged the Long Rajo,

3) Value price-appreciate

a) "Well, gentlemen! I didn't mean to disappoint my friend. Please convey my apologies to him that I am ashamed to be the son-in-law of a rich man my age!" Rajo Babanding's message.

b) "Rajo Babanding, you have rejected my proposal to edit your daughter Sabai. That means you insult me and as a respected person in the village of Si Tujuh, I don't accept this and you will suffer the consequences." Rajo Nan Panjang threatened while pointing his hand towards Rajo Babanding's face.

c) "O my guard, I warn you. Never underestimate Rajo Babanding. Even though he looks gentle, he is quite proficient in playing silat and his heart is as strong as a rock, be careful!" Said Rajo Nan Panjang to his three bodyguards.

4) The value of patience and unyielding spirit

When he found out that his best friend had a beautiful daughter, Rajo nan Panjang sent his messenger to propose to Sabai nan Aluih. He was very sure that Sabai's father would accept his proposal.

5) The value of cooperation.

Rajo nan Panjang was injured and fell heavily injured he said to his bodyguard, "Nan Kongkong, why are you silent? Immediately fire your rifle!" Hearing this order Nan Kongkong who was behind the bushes immediately aimed his rifle at Rajo Babanding. The sound of gunshots rattled from behind the bushes, bang... bang... bang...! Rajo Babanding fell to the ground covered in blood.

\section{b. Moral Values in the Folklore of Saba Nan Aluih}

1. Moral values in human relations with oneself

Responsibility for education.

In accordance with his name Sabai nan Aluih (smooth or gentle Sabai), he is virtuous, polite in speech, and respectful to the elderly. No wonder everyone loves it.

2. The moral value of human relations with other humans

a) Parent's advice to children

"My son Sabai, your dream means good. The burning barn means that rice will be harvested soon, the buffalo being stolen means our livestock will increase, the chicken being snatched by an eagle means that Mangkutak Alam will be proposed by someone," said Rajo Babanding while stroking his 

From the Region of Padang Tarok Baso, Agam

daughter's hair with the intention of calming Sabai nan Aluih's angry mind.

b) Advice between friends

Rajo Babanding's fight with Rajo Nan Panjang Rajo Babanding felt that his best friend had violated his manners because he dared to propose to his daughter directly.

c) Parental love for children

The boy's name is Mangkutak, while his brother's name is Sabai Nan Aluih. The story of a girl who doesn't get her father's love. His love was poured out for a boy named the Mangkutak.

Si Mangkutak only works with kites. All his requests were granted by his father. Love poured out to the Mangkutak. The expression was born, the flesh for the Mangkutak, the bones for the Sabai. But the beauty of Sabai Nan Aluib is famous far from his village.

d) Children's love for parents

Sabai is diligent in helping my mother. Sabai's beauty reached the ears of Rajo Nan Panjang in the village of Si Tujuh, Banda Dalam. He is a good friend of Rajo Babanding.

Meanwhile, her sister, Saba nan Aluih, is beautiful, gentle, diligent and often helps her mother. Free time is used to make lace and weave.

\section{CONCLUSION}

Based on the research results that have been described, a conclusion can be drawn. This is intended so that the opinions that have been expressed in the discussion can become a general and universal opinion. The aspect of the value of struggle that exists in the Saba Nan Aluib folklore is the value of struggle in terms of, (1) the value of being willing to sacrifice, (2) the value of unity, (3) the value of respect, (4) the value of patience and unyielding spirit, and (5) the value of cooperation. The moral values in the Saba Nan Aluib folklore are (a) the moral values in human relations with oneself are divided into, (1) responsibility for education (b) the moral values of human relations with other humans are divided into, (1) parental advice to children, (2) advice between friends, (3) parents' love for children, and (4) children's affection for parents

\section{ACKNOWLEDGEMENT}

Thank you to STAI Nurul Ilmi Tanjung Balai who has supported and facilitated the Lecturer Scientific Writing Training in September 2021 so that this research and manuscript can be completed properly.

\section{REFERENCES}

[1] Joyomartono, M. et al. (1990). Soul, Spirit, and $V$ alues of the Indonesian Nation's Struggle. Semarang: IKIP Semarang Press

[2] Haricahyono, C. (1995). Dimensions of Moral Education. Semarang. IKIP Semarang Press.

[3] Moleong, L. J. (1988). Qualitative Research Methodology. Bandung: PT Pemuda Rosdakarya.

[4] Nurgiyantoro, B. (2009). Theory of Fiction Studies. Yogyakarta: UGM.

[5] Rasjidi, H. M. (1984). Philosophical Problems. Jakarta. Moon Star.

[6] Sanusi, A. (2015). Value System: Alternative Faces of Education. Bandung: Scholarly nuances.

[7] Sayuti, S. A. (2000). Introduction to Fiction Prose. Yogyakarta. Gamma Media 